\title{
Recovery of municipal waste incineration bottom ash and water treatment sludge to water permeable pavement materials
}

\author{
Cheng-Fang Lin ${ }^{a}$, Chung-Hsin $\mathrm{Wu}^{\mathrm{b}, *}$, Hsiu-Mai Ho ${ }^{\text {a }}$ \\ ${ }^{a}$ Graduate Institute of Environmental Engineering, National Taiwan University, Taipei 106, Taiwan, ROC \\ ${ }^{\mathrm{b}}$ Department of Environmental Engineering, Da-Yeh University, 112, Shan-Jiau Road, Da-Tsuen, Chang-Hua 515, Taiwan, ROC
}

Accepted 27 September 2005

Available online 15 November 2005

\begin{abstract}
Water treatment plant sludge and municipal solid waste incinerator bottom ash are non-hazardous residues, and they can be reprocessed to produce useful materials for city public works. In this study, an effort was endeavored to investigate the properties of water permeable bricks made of water treatment sludge and bottom ash without involving an artificial aggregate step. The water treatment plant sludge was dried and ground, and the bottom ash was subjected to magnetic separation to remove ferrous metals. Both sludge and bottom ash were ground and sieved to a size of $<2 \mathrm{~mm}$. Different contents of water treatment sludge (70-95\% by weight) were mixed with bottom ash and the blocks were molded under a pressure of $110 \mathrm{~kg} / \mathrm{cm}^{2}$. Thereafter, the molded blocks were sintered at temperatures of $900-1200{ }^{\circ} \mathrm{C}$ for $60-360 \mathrm{~min}$. The compressive strength, permeability and water absorption rate of the sintered brick were examined and compared to relevant standards. The amount of bottom ash added in the mixture with water treatment sludge affects both the compressive strength and the permeability of the sintered bricks. The two effects are antonymous as higher bottom ash content will develop a beehive configuration and have more voids in the brick. It is concluded that a $20 \%$ weight content of bottom ash under a sintering condition of $1150{ }^{\circ} \mathrm{C}$ for $360 \mathrm{~min}$ can generate a brick with a compressive strength of $256 \mathrm{~kg} / \mathrm{cm}^{2}$, a water absorption ratio of $2.78 \%$ and a permeability of $0.016 \mathrm{~cm} / \mathrm{s}$.

(C) 2005 Elsevier Ltd. All rights reserved.
\end{abstract}

\section{Introduction}

For cities and countries with a high population density, the disposal of municipal wastes, primarily the solid wastes or incineration residues and water treatment and sewage sludge, has been an issue of concern. More cities have adapted source reduction and waste recycling or resource recovery of waste residues to combat waste disposal problems. For the last decade, researchers have developed various types of "wastes to materials" technologies and have shown successful practices in actual applications (Wiebusch and Seyfried, 1997; Liaw et al., 1998; Wiles and Shepherd, 1999; Barbieri et al., 2000). For example, Germany, France, and The Netherlands have been pro-

\footnotetext{
* Corresponding author. Fax: +886 55334958.

E-mail address: chunghsinwu@yahoo.com.tw (C.-H. Wu).
}

moting the use of treated ash or raw ash generated from municipal waste incinerators as bed materials in road construction work (Wiles and Shepherd, 1999; Barbieri et al., 2000). In addition to meeting heavy metal leaching criteria, most countries require that the reused bottom ash needs a 1-3-mo naturally weathering period for the purpose of chemical carbonation and physical stabilization (Wiles and Shepherd, 1999). Japanese researchers and municipal authorities have significantly advanced in the melting technologies of bottom and fly ash (Okamura et al., 1994; Nishigaki, 2000). The Japanese regulation even requires a compulsory melting process after municipal solid waste incineration in order to meet the goal of zero landfill. Accordingly, molten slag, originating either from bottom/fly ash or sewage sludge, can be converted into pavement bricks which are widely used in public areas in Japan, providing an excellent sustainable practice (Nishigaki, 2000). 
Most bricks sintered from molten slag, water treatment sludge and recovered sludge/ash mixtures can exhibit satisfactory engineering properties (Wiebusch and Seyfried, 1997; Liaw et al., 1998; Nishigaki, 2000). For instance, Nishigaki (2000) produced pavement bricks with compressive strength of $1278 \mathrm{~kg} / \mathrm{cm}^{2}$ from molten slag. The bricks made from water treatment sludge by a sintering process exhibit a compressive strength of $1150 \mathrm{~kg} / \mathrm{cm}^{2}$ at $1100{ }^{\circ} \mathrm{C}$, which is higher than the Japanese Industrial Standards (JIS) brick no. 3 of $200 \mathrm{~kg} / \mathrm{cm}^{2}$ and Chinese National Standards (CNS) brick no. 1 of $150 \mathrm{~kg} / \mathrm{cm}^{2}$ (Sun, 2001). However, the major point that limits its application as pavement bricks is the low water permeability, especially when considering the heat phenomena encountered. Without using special materials and procedures, a permeability of $0.01 \mathrm{~cm} / \mathrm{s}$ is almost unachievable in regular brick-making process (Ho, 2003).

Natural clay has been widely used in making bricks with low water permeability, because after sintering process the compressed fine clay particles will seal the inner pores to limit water permeating through the brick. If replacing clay with coarse sand, the brick will exhibit a better water permeable property but bears a low compressive strength due to the larger pores within the brick. Therefore, some researchers have developed new methods making water permeable blocks while using recovered materials such as melting slag, bottom and fly ash, and water treatment and sewage sludge (Okamura et al., 1994). Those methods all involve a key step of producing artificial aggregate which acts as coarse medium providing pores for water to infiltrate through. At the same time, clay is added to serve as binding agents during the sintering process. Some successful examples have been reported from Okamura et al. (1994) and Nishigaki (2000). The bricks produced generally have comparable compressive strength of larger than $170 \mathrm{~kg} / \mathrm{cm}^{2}$ and reliable water permeability larger than $0.01 \mathrm{~cm} / \mathrm{s}$.

There are several factors affecting the physical properties of sintered bricks, especially the compressive strength and water permeability. The most significant factors seem to be sludge granular size and sintering temperature (Nowok et al., 1990; Okuno and Takahashi, 1997; Liaw et al., 1998; Barbieri et al., 2000). It is assumed that the sintering process cements granular materials together by melting the surface thin layers (German, 1996). Lower temperatures may not generate an appropriate surface melting effect, and higher temperatures may cause an over-melting phenomenon. Hence, the compressive strength is highly dependent on sintering temperature. In another aspect, porosity (open pores) is a key element in making high water-permeable bricks. A better way of preparing high water-permeable bricks is to adapt coarse granular materials, which will have enough coarse pores and channels in a compacted block. Controlling the water adsorption of bricks is important with respect to avoiding moss growth, iced surface and whitening, aesthetic and safety considerations. Tokyo Metro standard has set a recommended range of $0.1-$
$10 \%$; however, in order to control the above-mentioned issues, Okuno and Takahashi (1997) suggested a water absorption ratio of $<5 \%$.

In this current study, a simplified method was developed to produce water-permeable bricks with compatible compressive strength without using natural clay and producing artificial aggregate steps. With a high content of $\mathrm{Al}_{2} \mathrm{O}_{3}$ and $\mathrm{SiO}_{2}$, water treatment sludge was used both as binding and filling agent and the sieved bottom ash served as structural aggregate to produce water-permeable bricks with compatible engineering properties. Experiments were conducted to investigate the effects of sintering temperature, sintering period, and ratio of water treatment sludge/bottom ash on the physical properties of sintered products.

\section{Materials and methods}

\subsection{Materials}

Water treatment sludge was obtained from the Taipei water treatment plant. The sludge cake obtained after the dewatering process was ground and sieved to remove big granular materials before it was further dried at $105^{\circ} \mathrm{C}$ for $48 \mathrm{~h}$. Bottom ash was obtained from two different municipal waste incinerators. The granular size distribution of the bottom ash ranged from 0.3 to $20 \mathrm{~mm}$. The bottom ash was oven-dried at $105^{\circ} \mathrm{C}$ for $48 \mathrm{~h}$ and then magnetically processed to remove ferrous metals. Both water treatment sludge and bottom ash were then again separately grinded and sieved to a granular size $<2.0 \mathrm{~mm}$ before they were used for the subsequent sintering experiments.

The heavy metal concentrations and other parameters of water treatment sludge and bottom ash are listed in Table 1. The total concentrations of heavy metals in water treatment sludge and bottom ash were high. As a consequence, the toxicity characteristic leaching procedure (TCLP, US EPA Method 1311) was conducted to examine heavy metal leaching (Table 2). The results of the TCLP for water treatment sludge and bottom ash show that neither of these two materials is classified as hazardous material.

Table 1

Characteristics of the water treatment sludge and bottom ash

\begin{tabular}{lccc}
\hline & $\begin{array}{l}\text { Water treatment } \\
\text { sludge }\end{array}$ & Bottom ash & \\
\cline { 3 - 4 } & & Plant A & Plant B \\
\hline Total concentration & 104 & 443 & 219 \\
$\mathrm{Cr}(\mathrm{mg} / \mathrm{kg})$ & 2.7 & 745 & 2902 \\
$\mathrm{Cu}(\mathrm{mg} / \mathrm{kg})$ & $<0.1$ & 5.5 & 2.7 \\
$\mathrm{Cd}(\mathrm{mg} / \mathrm{kg})$ & 16.6 & 750 & 476 \\
$\mathrm{~Pb}(\mathrm{mg} / \mathrm{kg})$ & 6.7 & 10.5 & 11 \\
$\mathrm{pH}$ & 4.2 & 0.5 & 0.4 \\
$\mathrm{Moisture}(\%)$ & 11.9 & 6.1 & 3.1 \\
Loss on ignition $(\%)$ & & & \\
$\quad(600 \pm 25,3 \mathrm{~h})$ & 0.2 & 0.8 & 0.5 \\
$\mathrm{Cl}^{-}(\%)$ &
\end{tabular}

The acid/alkali degree of the material leached in water was measured as $\mathrm{pH}$. 
Table 2

Heavy metals leaching of the water treatment sludge and bottom ash by TCLP (US EPA Method 1311)

\begin{tabular}{|c|c|c|c|c|}
\hline & \multirow{2}{*}{$\begin{array}{l}\text { Water treatment } \\
\text { sludge }\end{array}$} & \multicolumn{2}{|c|}{ Bottom ash } & \multirow{2}{*}{$\begin{array}{l}\text { Standard of limit } \\
\text { for hazardous } \\
\text { waste inTaiwan }\end{array}$} \\
\hline & & Plant A & Plant B & \\
\hline $\mathrm{Cr}(\mathrm{mg} / \mathrm{L})$ & ND & 0.88 & 0.64 & 5 \\
\hline $\mathrm{Cr}^{6+}(\mathrm{mg} / \mathrm{L})$ & ND & ND & ND & 2.5 \\
\hline $\mathrm{Cu}(\mathrm{mg} / \mathrm{L})$ & ND & 1.52 & 1.56 & 15 \\
\hline $\mathrm{Cd}(\mathrm{mg} / \mathrm{L})$ & ND & 0.009 & 0.014 & 1 \\
\hline $\mathrm{Pb}(\mathrm{mg} / \mathrm{L})$ & ND & 3.96 & 1.80 & 5 \\
\hline
\end{tabular}

Detection limit $=0.1 \mathrm{mg} / \mathrm{L}$.

Table 3 shows the elemental compositions of water treatment sludge and bottom ash. The water treatment sludge is primary made up of $21 \% \mathrm{Al}_{2} \mathrm{O}_{3}$ and $54 \% \mathrm{SiO}_{2}$, and the bottom ash consists of $40 \% \mathrm{SiO}_{2}, 20 \% \mathrm{CaO}, 9.4 \% \mathrm{Fe}_{2} \mathrm{O}_{3}$, and $7.9 \% \mathrm{Al}_{2} \mathrm{O}_{3}$.

\subsection{Methods}

The granular sizes of the samples were separated into the intervals of $<0.125,0.125-0.25,0.25-0.5,0.5-1.0$, and $1.0-2.0 \mathrm{~mm}$ with a standard sieving apparatus. The samples thus prepared were subjected over $2 \mathrm{~min}$ to a molding pressure of $110 \mathrm{~kg} / \mathrm{cm}^{2}$ to prepare working blocks. Sintering temperatures were set in the range of 900 $1200{ }^{\circ} \mathrm{C}$ using a Nabertherm N100/H ceramotherm (Germany). The oven temperature was increased at a rate of $3-5^{\circ} \mathrm{C} / \mathrm{min}$. After reaching the pre-determined sintering temperature, the sintering period ranged from 60 to $360 \mathrm{~min}$ according to the experimental protocol. Fig. 1 shows the production process of water permeable pavement. The variations of parameters in the production process are presented in Table 4.

Changes in physical characteristic changes including volume shrinkage ratio, apparent density (ASTM D854-92), water adsorption ratio (CNS A3007), compressive strength (CNS 13295), and water permeability (JIS A1218) of the sintered bricks were measured and were compared to the available relevant standards (ASTM D854-92, CNS A3007, CNS 13295 and JIS A1218). The test and measurement procedures followed CNS standards or ASTM guidelines. The water permeability of bricks was determined with a constant water head apparatus by applying Darcy's law.

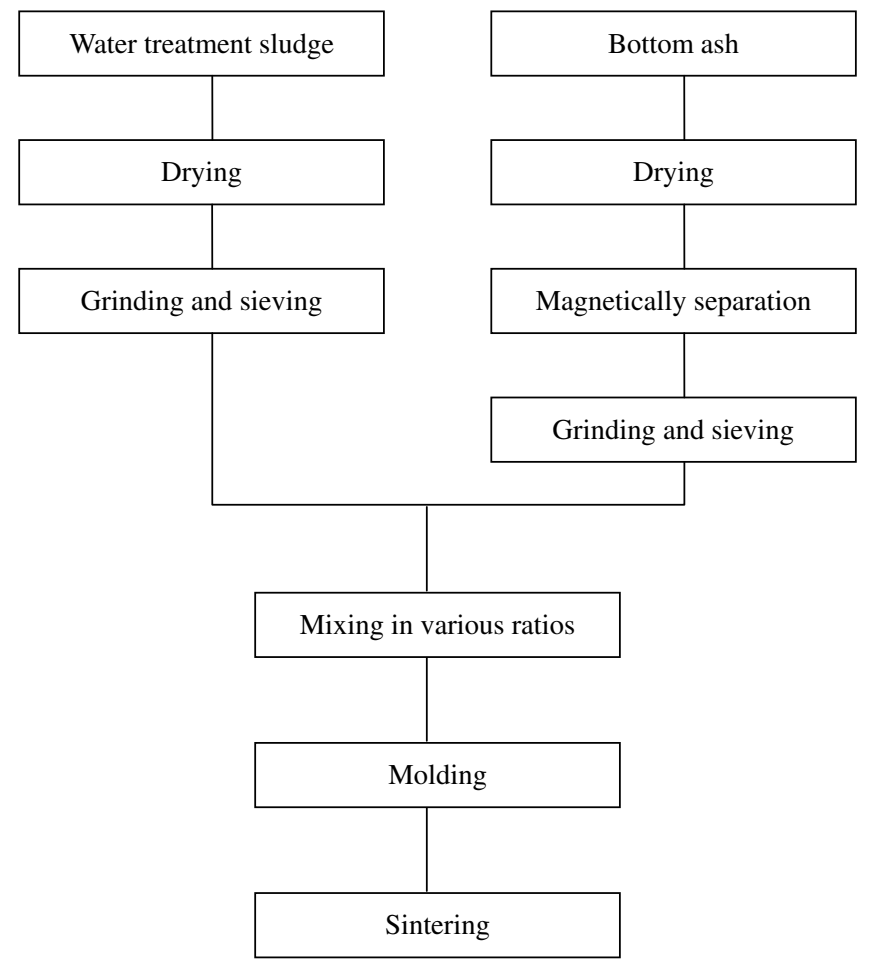

Fig. 1. Production process of water permeable pavement.

During the hydraulic experiments, a constant water flux condition should be reached before the equilibrium water flux was used in calculating Darcy hydraulic conductivity. The morphology of the sintered products was also examined by scanning electron microscopy (SEM, JEOL, JSM6300 , Japan) to reveal the surface pore distribution.

Table 4

The variations of parameters in water permeable pavement production

\begin{tabular}{ll}
\hline Parameters & Variations \\
\hline Drying & $105{ }^{\circ} \mathrm{C}, 48 \mathrm{~h}$ \\
Sieving $(\mathrm{mm})$ & $<0.125,0.125-0.25$, \\
& $0.25-0.5,0.5-1.0,1.0-2.0$ \\
Water treatment sludge ratio $(\%)$ & $70,75,80,85,90,95,98$ \\
Bottom ash ratio $(\%)$ & $2,5,10,15,20,25,30$ \\
Molding & $110 \mathrm{~kg} / \mathrm{cm}^{2}, 2 \mathrm{~min}$ \\
Sintering temperature $\left({ }^{\circ} \mathrm{C}\right)$ & $900,1000,1050,1100,1150,1200$ \\
Sintering time $(\min )$ & $60,120,240,360$ \\
\hline
\end{tabular}

Table 3

Elemental compositions (\%) of water treatment sludge, bottom ash and some reference materials

\begin{tabular}{|c|c|c|c|c|c|c|}
\hline Compounds & $\begin{array}{l}\text { Natural coarse } \\
\text { aggregate }\end{array}$ & $\begin{array}{l}\text { Natural fine } \\
\text { aggregate }\end{array}$ & $\begin{array}{l}\text { Bottom ash } \\
\text { (Plant A) }\end{array}$ & $\begin{array}{l}\text { Water treatment } \\
\text { sludge }\end{array}$ & Portland cement & $\begin{array}{l}\text { CNS standard of } \\
\text { blast-furnace slag }\end{array}$ \\
\hline$\overline{\mathrm{SiO}_{2}}$ & 85.5 & 91.0 & 39.7 & 53.6 & 22.1 & 33.5 \\
\hline $\mathrm{CaO}$ & 0.3 & 0.1 & 19.9 & 0.3 & 64.6 & 37.0 \\
\hline $\mathrm{K}_{2} \mathrm{O}$ & 1.3 & 1.2 & 1.2 & - & - & - \\
\hline $\mathrm{Na}_{2} \mathrm{O}$ & 0.4 & - & 4.7 & - & - & - \\
\hline $\mathrm{Al}_{2} \mathrm{O}_{3}$ & 6.7 & 4.8 & 7.9 & 20.9 & 5.4 & 15.7 \\
\hline $\mathrm{SO}_{4}^{2-}$ & - & - & 0.9 & - & - & 2.0 \\
\hline
\end{tabular}




\section{Results and discussion}

\subsection{Compressive strength of water treatment sludge}

The loss on ignition $\left(600^{\circ} \mathrm{C}\right)$ was calculated as the amount of organic matter remaining in the surface of the water treatment sludge and in the bottom ash. The LOI of the water treatment sludge and the ash was measured at $600{ }^{\circ} \mathrm{C}$, and found to be $12 \%, 6 \%$ and $3 \%$ organic matter in Table 1. The materials were exposed to a higher temperature of $900-1200{ }^{\circ} \mathrm{C}$ in the following sintering process. Hence, no residual organic matter was left in the bricks. The results of TCLP revealed that all heavy metal leaching was below limit values for hazardous waste in Taiwan (Table 2). Accordingly, the mobilization of organic matter and heavy metals was negligible; both water treatment sludge and bottom ash can thus be reused as non-hazardous resources.

The experimental work first examined the confounding effects of sintering temperature and granular size on the physical strength and water permeability of the sintered bricks. Fig. 2 shows the compressive strength of sintered bricks after $60 \mathrm{~min}$ as a function of sludge particle size at various sintering temperatures. Both sintering temperature and particle size have significant effect on the compressive strength of sintered bricks; obviously, there is a confounding effect which affects the brick compressive strength. The general trend is that the compressive strength increases with sintering temperature in the range of $900-1200^{\circ} \mathrm{C}$. This confirms the results of other studies where compressive strength also increases with increasing sintering temperature (Wiebusch and Seyfried, 1997; Liaw et al., 1998). A study using incinerated sewage sludge in manufacturing bricks showed that the compressive strength increases with firing temperature to $1037^{\circ} \mathrm{C}$ and decreases thereafter (Okuno and Takahashi, 1997). A similar phenomenon was observed in this study in the category of 1-2 $\mathrm{mm}$ water treatment sludge where a sintering temperature of $1200^{\circ} \mathrm{C}$ did not produce higher compressive strength in the bricks than a sintering temperature of $1100^{\circ} \mathrm{C}$. It is likely that gasification of the matrix occurs as temperature may be over the melting point of several compounds. In fact, Okuno and Takahashi (1997) suggested the optimum firing temperatures for the brick-manufacturing process to be between 1070 and $1080^{\circ} \mathrm{C}$. The present study shows that a granular size of $0.25-0.5 \mathrm{~mm}$

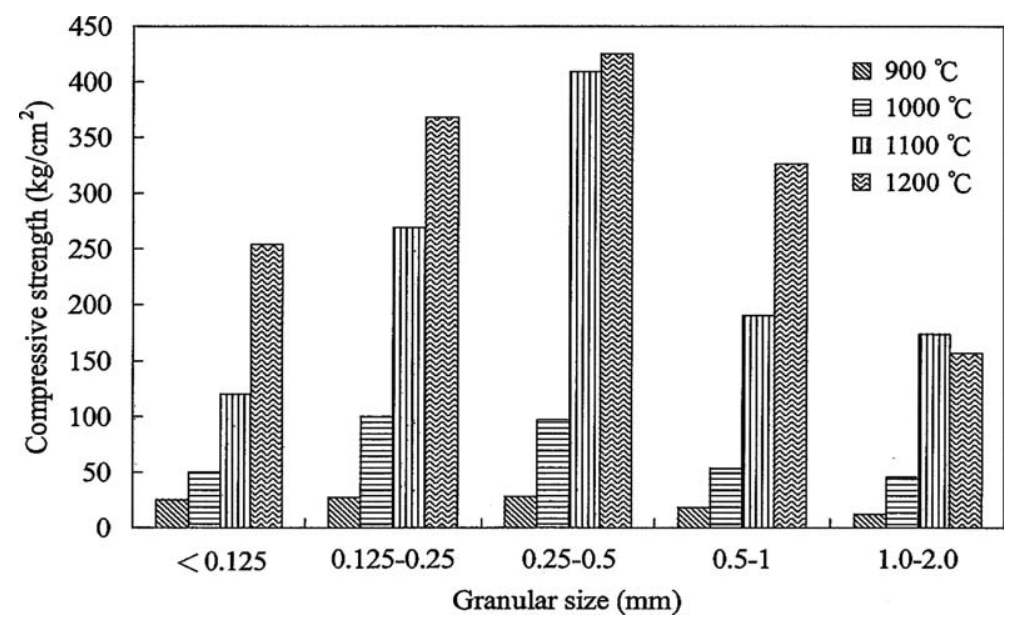

Fig. 2. The effects of sludge granular sizes and sintering temperatures on compressive strength of sintered brick.

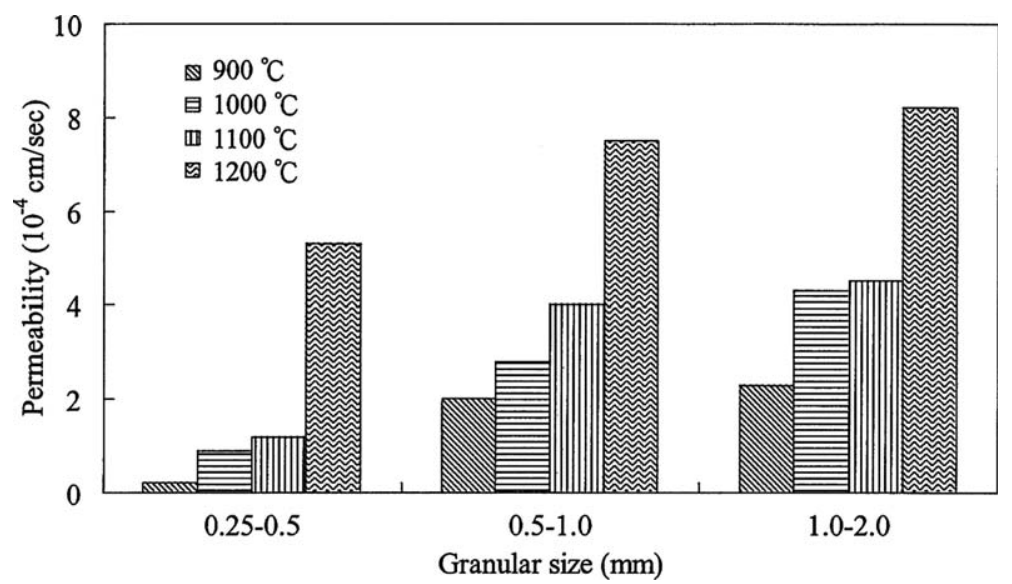

Fig. 3. The brick water permeability under various water treatment sludge granular size and sintering temperature. 


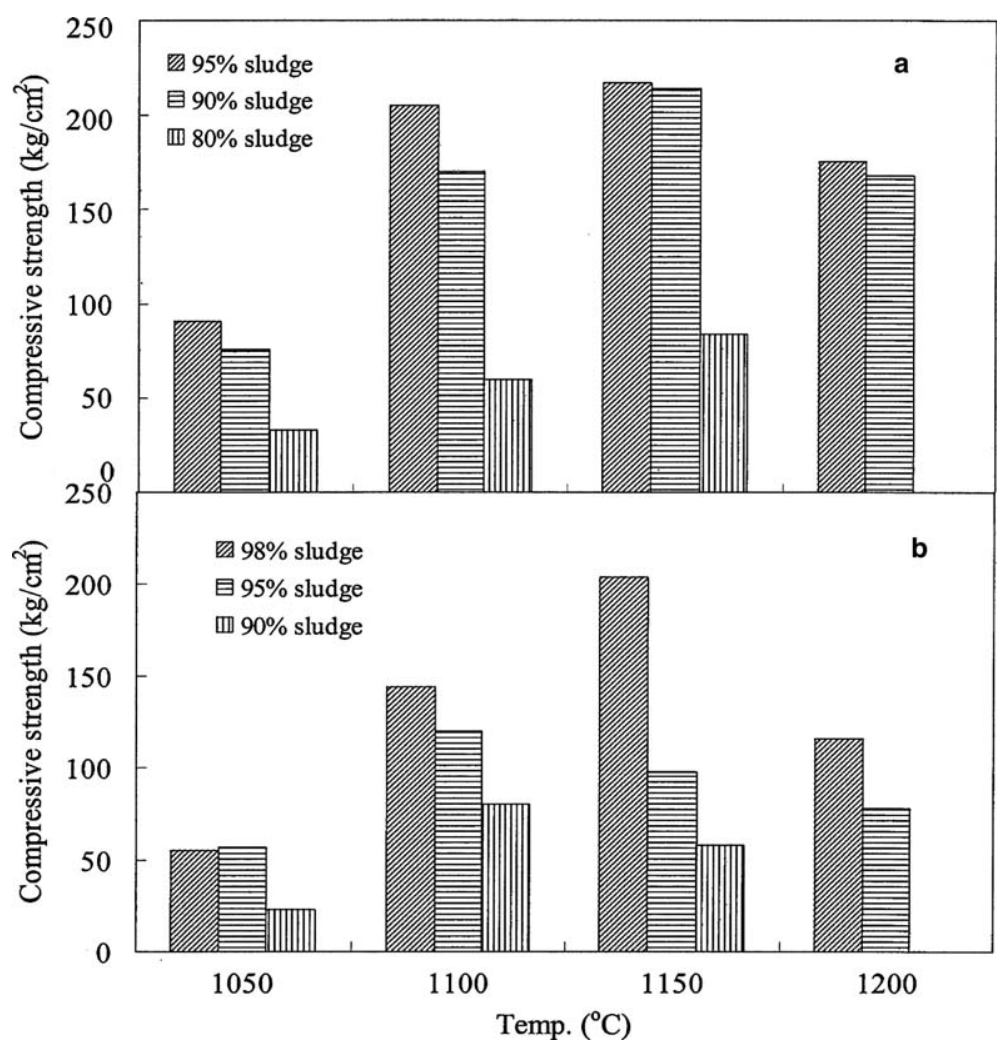

Fig. 4. The compressive strength of bricks processed by mixtures of water treatment sludge and bottom ash at various sintering temperatures: (a) granular size, $0.5-1.0 \mathrm{~mm}$; (b) granular size, $1.0-2.0 \mathrm{~mm}$.

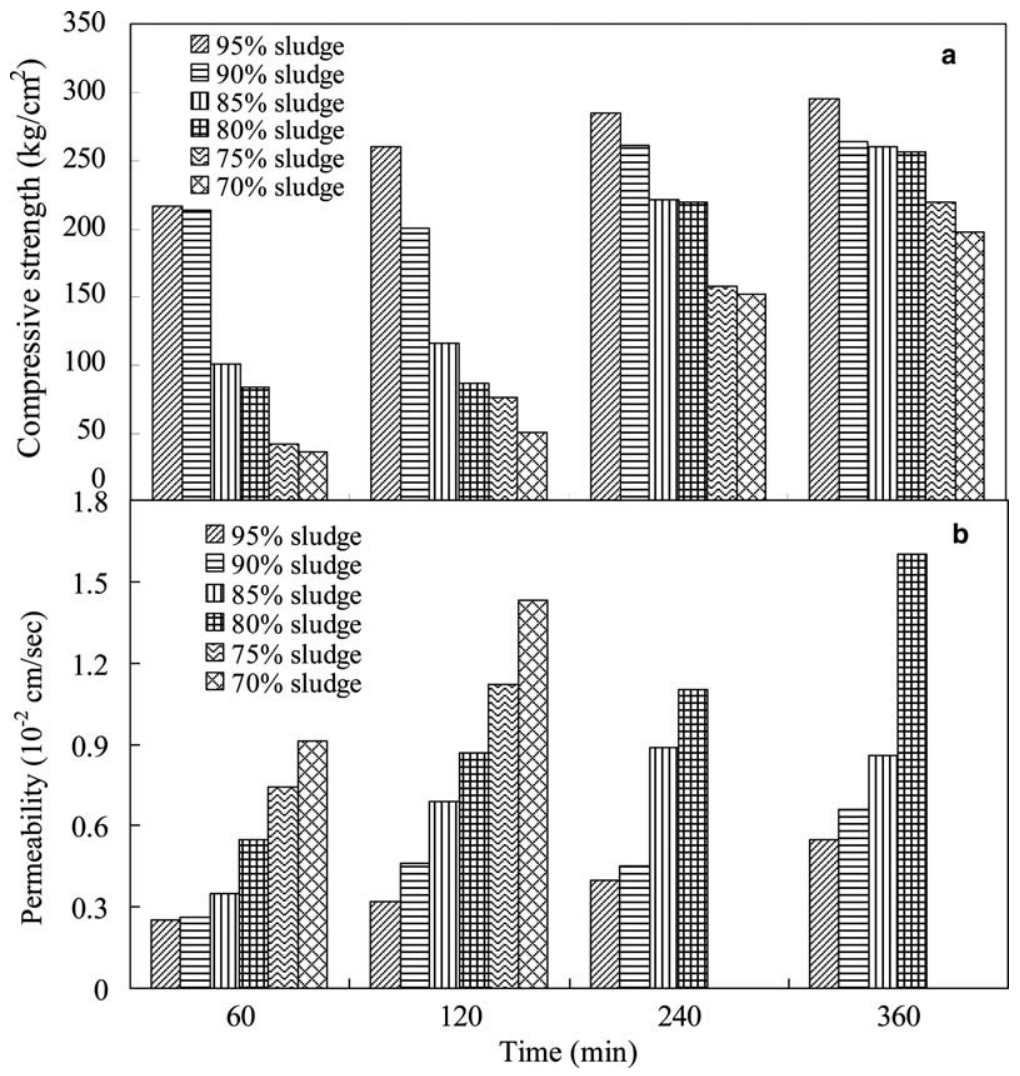

Fig. 5. The compressive strength (a) and permeability (b) of the sintered bricks at $T=1150{ }^{\circ} \mathrm{C}$ with water treatment sludge content from $70 \%$ to $95 \%$. Time means sintering period. 
and a sintering temperature of $1100-1200{ }^{\circ} \mathrm{C}$ produce bricks with a better physical strength. A smaller or larger granular size may not contribute to the structural integrity of the bricks, although the JIS R 1250 standard brick no. 3 only sets the threshold compressive strength at $200 \mathrm{~kg} / \mathrm{cm}^{2}$.

\subsection{Permeability of water treatment sludge}

Fig. 3 shows the permeability of the sintered bricks $(t=60 \mathrm{~min}$ ) made of sludge. With the same sintering temperature, larger sludge particles normally result in produc- ing higher permeability bricks. The best permeability obtained in this experimental run is near $8 \times 10^{-4} \mathrm{~cm} / \mathrm{s}$ at $1200{ }^{\circ} \mathrm{C}$, which is far less than most published standards (JIS A1218) $\left(1 \times 10^{-2} \mathrm{~cm} / \mathrm{s}\right)$. If the three granular sizes range $(0.25-0.5,0.5-1.0$, and $1.0-2.0 \mathrm{~mm})$ and two temperatures $\left(1100\right.$ and $\left.1200{ }^{\circ} \mathrm{C}\right)$ in Figs. 2 and 3 are compared, it is noticed that the compressive strength is in opposite relation to the permeability of the sintered bricks. It can be reasoned that unsealed pores and channels in the block contribute to the permeability but diminish the physical strength of bricks. Accordingly, sludge with granular size
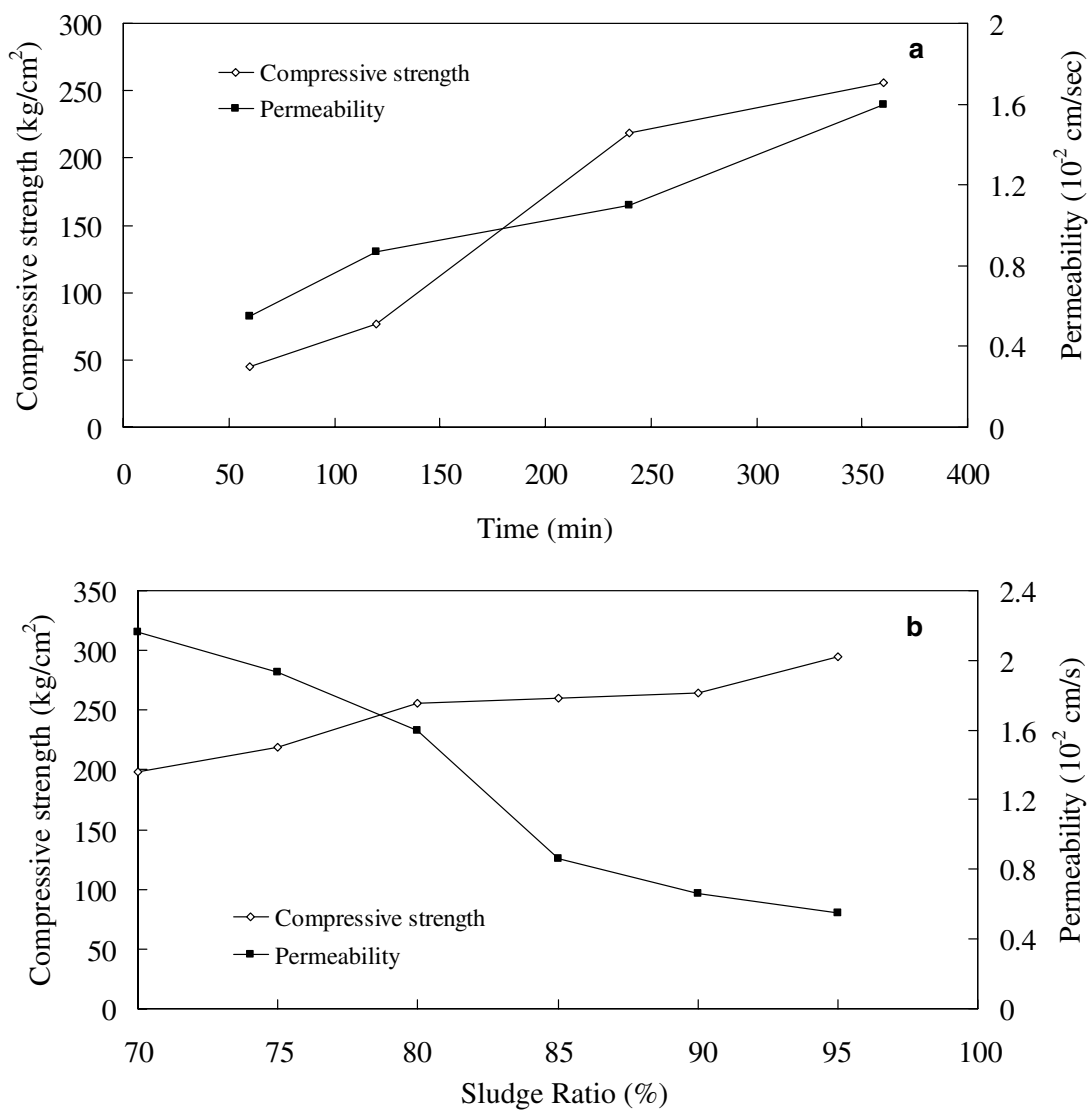

Fig. 6. Compressive strength and permeability of the sintered bricks as functions of sintering period for: (a) $80^{\circ} \%$ sludge at $1150{ }^{\circ} \mathrm{C}$; (b) $360 \mathrm{~min}$ at $1150{ }^{\circ} \mathrm{C}$.

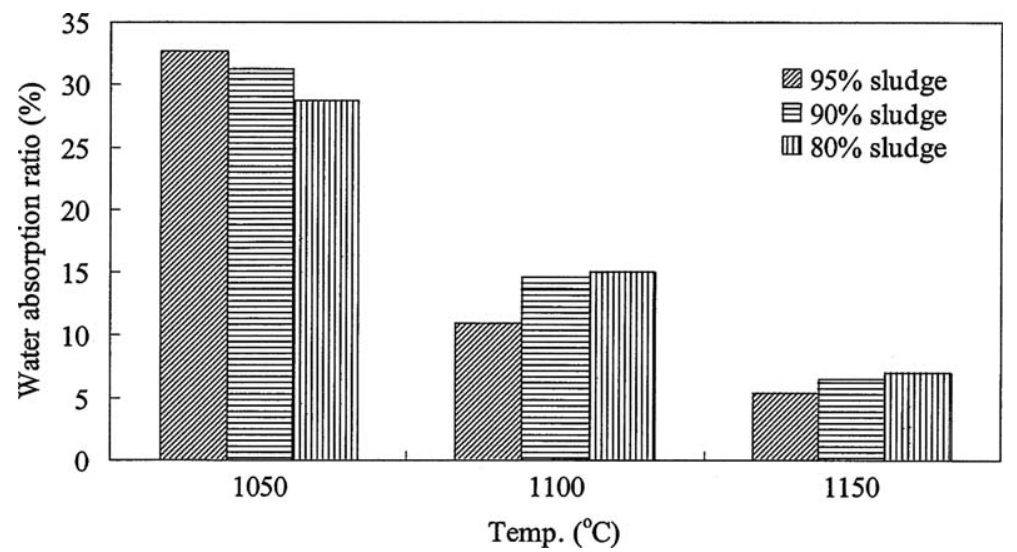

Fig. 7. The water absorption ratio of the sintered bricks produced from water treatment sludge and bottom ash mixtures at three sintering temperatures. 
of $0.5-2.0 \mathrm{~mm}$ was used in profiling the characteristics of water permeable bricks with the addition of bottom ash.

\subsection{Properties of water treatment sludgelbottom ash bricks}

Fig. 4 shows the compressive strength of bricks processed by mixtures of sludge and bottom ash (80-95\% sludge) at various sintering temperatures. The particle sizes used in the experimental runs were $0.5-1.0 \mathrm{~mm}$ (Fig. 4a) and $1.0-2.0 \mathrm{~mm}$ (Fig. 4b). It is apparent from Fig. 4 that an increase in bottom ash content decreases the compressive strength of the sintered bricks - this phenomenon was also reported by Liaw et al. (1998). However, Wiebusch and Seyfried (1997) report that the compressive strength increases at first with low ash addition of 10 $\mathrm{wt} \%$, but decreases with further heightening of ash content. A temperature of $1150^{\circ} \mathrm{C}$ seems to produce bricks with the highest compressive strength of near $200 \mathrm{~kg} / \mathrm{cm}^{2}$. Therefore, the brick properties with various contents of bottom ash at $1150^{\circ} \mathrm{C}$ were further examined. Fig. 5 shows the compressive strength and permeability of the sintered bricks with water treatment sludge content from $70 \%$ to 95\%. In Fig. 5a, a better strength is developed as sintered period is extended from 60 to $360 \mathrm{~min}$. For example, the compressive strength of sintered brick fired during $60 \mathrm{~min}$ with an addition of $70 \%$ water treatment sludge is only $40 \mathrm{~kg} / \mathrm{cm}^{2}$, far below the required value. A sintering period of $360 \mathrm{~min}$, however, can develop strength of over $200 \mathrm{~kg} /$ $\mathrm{cm}^{2}$ even at a $30 \%$ weight replaced by bottom ash. Without enough sintering time, the addition of bottom ash will significantly deteriorate the physical strength of sintered bricks. Nowok et al. (1990) also reported that sintered product strength from coal fly ash increased as firing period was extended. In this work, the addition of bottom ash in the sludge matrix might form micro or mini pores (SEM photos in Fig. 9) caused by organic volatilization and gas expansion during the sintering process, resulting in the fractural brick strength. The phenomenon is particularly noticeable in the case where the addition of water treatment sludge is $<80 \%$. Accordingly, the physical strength has a significant relationship to the water permeability as shown in Fig. 5b. Contrary to the strength, permeability is significantly affected by the content of bottom ash in the mixture. It is evident that bottom ash serves as a key element providing the paths for water to infiltrate through the brick. In most published works on manufacturing water permeable bricks, the critical step seems to be the preparation of aggregates that are cemented either by sintering accelerator or other materials such as clay slurry or ash (Okamura et al., 1994; Nishigaki, 2000). Additionally, ferrous materials need to be removed to prevent bubbling and other adverse problems. The primary function of aggregates is to offer continuous pores in the bricks, in addition to providing strength. In this work, bottom ash was used to provide connected pores while using sludge to offer strength. There are four groups of sintering combinations that are able to achieve the $1 \times 10^{-2} \mathrm{~cm} / \mathrm{s}$ standard: $70 \%$ and $75 \%$ water treatment sludge at $120 \mathrm{~min}$ and $80 \%$ water treatment sludge at 240 and $360 \mathrm{~min}$.

\subsection{Effects on compressive strength, permeability and water absorption ratio}

Fig. 6a and $\mathrm{b}$ presents compressive strength and permeability of the sintered bricks as functions of sintering period and sludge content at $1150{ }^{\circ} \mathrm{C}$, respectively. In Fig. 6a, both compressive strength and permeability increase over sintering period at $1150{ }^{\circ} \mathrm{C}$ and $80 \%$ content of water treatment sludge. To achieve a permeability of $1 \times 10^{-2} \mathrm{~cm} / \mathrm{s}$, a sintering period of $180 \mathrm{~min}$ is necessary but the corresponding compressive strength obtained is only $150 \mathrm{~kg} / \mathrm{cm}^{2}$. A minimum of $200 \mathrm{~kg} / \mathrm{cm}^{2}$ strength would require at least $230 \mathrm{~min}$ sintering period while maintaining a permeability larger than $1 \times 10^{-2} \mathrm{~cm} / \mathrm{s}$. In Fig. $6 \mathrm{~b}$, the contradictory results between compressive strength and permeability of the sintered bricks are evident. Increasing bottom ash content definitely deteriorates the physical integrity of brick due to the voids retained in the matrix. With $360 \mathrm{~min}$ of sintering period, the compressive strength of sintered bricks can easily exceed $200 \mathrm{~kg} / \mathrm{cm}^{2}$; however, the water treatment

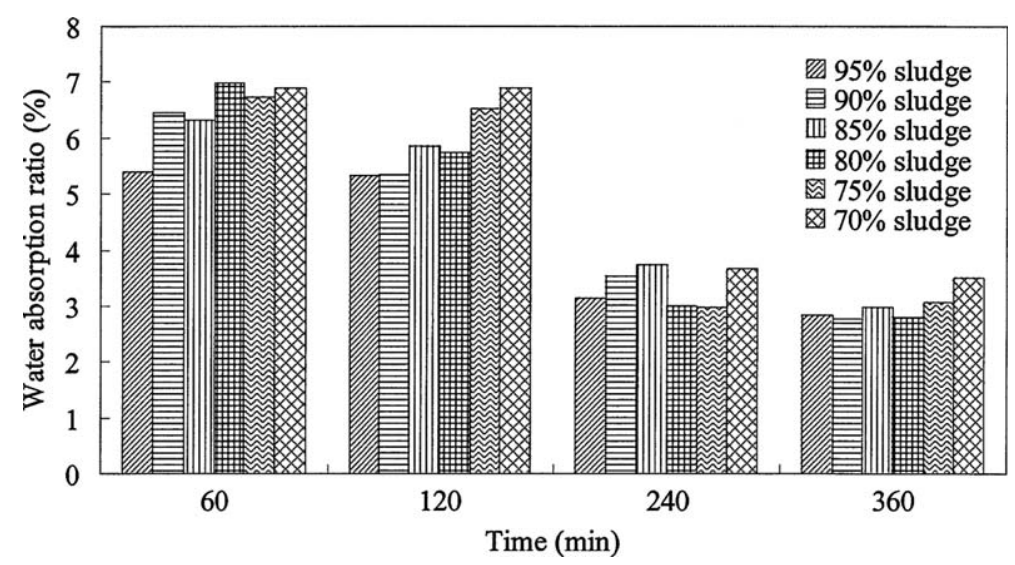

Fig. 8. The water absorption ratio of the sintered bricks produced from water treatment sludge and bottom ash mixtures as a function of sintering period. 
sludge addition has to be over $83 \%$ in order to meet the $1 \times 10^{-2} \mathrm{~cm} / \mathrm{s}$ standard.

Fig. 7 shows the water absorption ratio of the sintered bricks produced from water treatment sludge and bottom ash mixtures. The water absorption ratios vary from near $5 \%$ to $32 \%$ by weight. In the literature, the general trend is that a higher sintering temperature results in a lower water adsorption ratio of bricks (Wiebusch and Seyfried, 1997; Liaw et al., 1998) and the content of bottom ash in mixture plays an insignificant role in terms of temperature effect. Water absorption ratio can be easily controlled by a

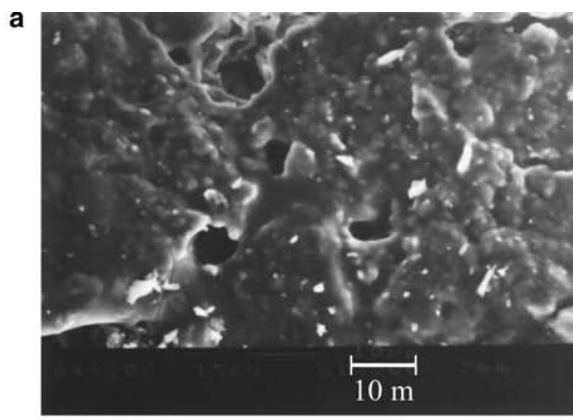

b

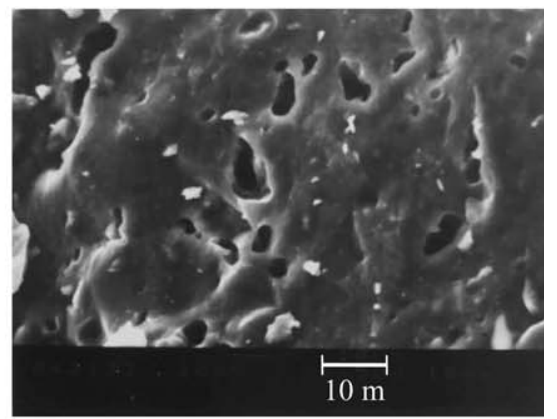

c

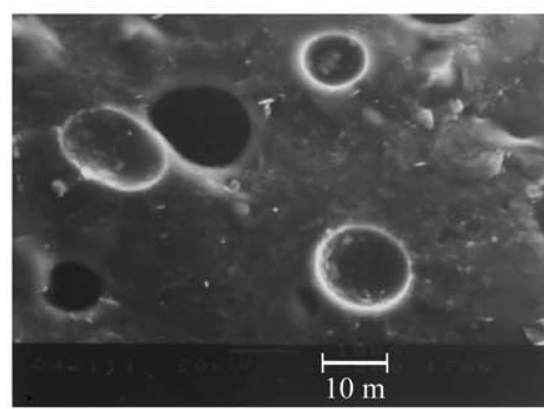

d

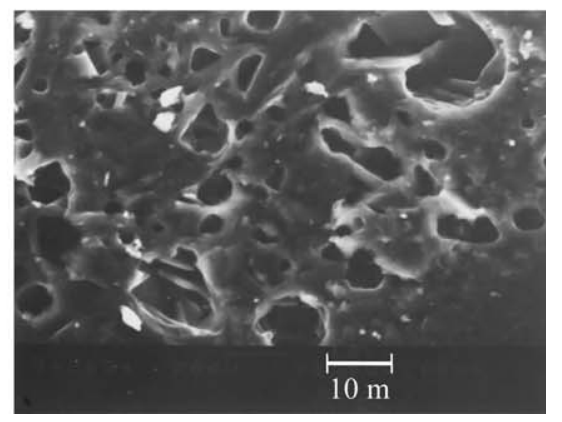

Fig. 9. The SEM photographs of the products sintered at $1200{ }^{\circ} \mathrm{C}$ for 30 min: (a) water treatment sludge $=95 \%$; (b) water treatment sludge $=90 \%$; (c) water treatment sludge $=80 \%$; (d) water treatment sludge $=70 \%$. higher sintering temperature as shown in Fig. 7. To further examine the effect of water treatment sludge content on the water absorption ratio of sintered bricks, the water treatment sludge content was increased from $70 \%$ to $95 \%$ and the blocks were sintered at $1150{ }^{\circ} \mathrm{C}$ from 60 to $360 \mathrm{~min}$. It was found in Fig. 8 that all of the combinations can yield a water absorption ratio $<10 \%$. A longer sintering period ( $\geqq 240 \mathrm{~min}$ ) stabilizes the variation due to the ash effect and lowers water adsorption ratio to $<5 \%$. It can be reasoned that both higher sintering temperature and longer sintering period promote melting on material surfaces and hence reduce void volume in the matrix.

Sintered bricks prepared in this work were also subject to SEM for microstructure observations. Fig. 9a-d shows the SEM photographs of the products at $1200{ }^{\circ} \mathrm{C}$ after $30 \mathrm{~min}$. The particle size of sludge and bottom ash are $0.5-1.0 \mathrm{~mm}$ and the water treatment sludge contents range from $95 \%$ to $70 \%$ The formation of viscose fluid deposits after material melting process is noted. There is also formation of random voids with various sizes in the matrix. These are probably formed due to the gasification of organic residues or calcium compounds which are originally present in bottom ash. This phenomenon is most significant in Fig. 9d, where $70 \%$ addition of water treatment sludge produces a beehive structure. Obviously, the permeability is promoted with more bottom ash mixture but the physical strength is deteriorated.

\section{Conclusions}

In most municipalities, the residues from water treatment plants and solid waste incinerators are emerging issues of environmental concern. Many technologies have been developed to convert these residues to useful materials such as bricks used in public facilities. In this work, nonhazardous MSWI bottom ash was used as aggregate material and was added to water treatment sludge to produce water permeable bricks, which are environment-friendly products to serve as pavement bricks in urban areas. The general trend is that the compressive strength increases with sintering temperature in the range of $900-1200^{\circ} \mathrm{C}$. With the same sintering temperature, larger sludge particles normally result in producing higher permeability bricks. The amount of bottom ash added in mixture with water treatment sludge does affect both the compressive strength as well as permeability of the sintered bricks. The two effects are antonymous as higher bottom ash content will develop a bee hive configuration and have more voids in the brick. In this work, bottom ash was used to provide connected pores while using sludge to offer strength. Water absorption ratio can be easily controlled by a higher sintering temperature. It is suggested that a $80 \%$ weight content of water treatment sludge under a sintering condition of $1150{ }^{\circ} \mathrm{C}$ for $360 \mathrm{~min}$ can generate a brick with a compressive strength of $256 \mathrm{~kg} / \mathrm{cm}^{2}$, a water absorption ratio of $2.78 \%$ and a permeability of $0.016 \mathrm{~cm} / \mathrm{s}$. This sintered product can meet most pavement brick standards. 


\section{Acknowledgement}

This research was funded by National Science Council of the Republic of China under project number: NSC 912211-E-002-009.

\section{References}

Barbieri, L., Corradi, A., Lancellotti, I., 2000. Bulk and sintered glassceramics by recycling municipal incinerator bottom ash. Journal of the European Ceramic Society 20, 1637-1643.

German, R.M., 1996. Sintering Theory and Practice. Wiley Interscience, New York, USA.

Ho, H.M., 2003. Resource recovery of incinerator bottom ash and water treatment sludge. Master Thesis, Graduate Institute of Environmental Engineering, National Taiwan University, Taiwan.

Liaw, C.T., Chang, H.L., Hsu, W.C., Huang, C.R., 1998. A novel method to reuse paper sludge and co-generation ashes from paper mill. Journal of Hazardous Materials 58, 93-102.
Nishigaki, M., 2000. Producing permeable blocks and pavement bricks from molten slag. Waste Management 20, 185-192.

Nowok, J.W., Benson, S.A., Jones, M.L., Kalmanovitch, D.P., 1990. Sintering behavior and strength development in various coal ashes. Fuel 69, 1020-1027.

Okamura, T., Masuno, K., Kaneko, M., 1994. Sintering system for recycling plant fly ash and bottom ash from incineration plant. Ebara Engineering Review 164, 38-42.

Okuno, N., Takahashi, S., 1997. Full scale application of manufacturing bricks from sewage. Water Science and Technology 36, 243-250.

Sun, K.D., 2001. Reuse of water treatment plant sludge and dam sediment in brick and Pavior-making. Master Thesis, National Chiao-Tung University, Taiwan.

Wiebusch, B., Seyfried, C.F., 1997. Utilization of sewage sludge ashes in the brick and tile industry. Water Science and Technology 36, 251258.

Wiles, C., Shepherd, P., 1999. Beneficial use and recycling of municipal waste combustion residues - a comprehensive resource document. National Renewable Energy Laboratory, No. IT635151, Golden, CO, USA. 